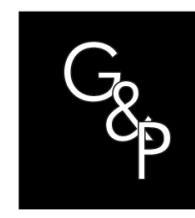

\title{
Practices of knowledge management in organizational processes of town hall of the AMUSEP region: a research agenda
}

\author{
Práticas da gestão do conhecimento em processos organizacionais \\ de prefeituras municipais da região da AMUSEP: uma agenda de \\ pesquisa
}

\author{
Arthur Gualberto Bacelar da Cruz Urpia ${ }^{1}$ (D), Rejane Sartori ${ }^{1}$ (D), Caio Pisconti Machado ${ }^{1}$ (D) \\ ${ }^{1}$ Centro Universitário Cesumar - Unicesumar, Programa de Pós-graduação em Gestão do Conhecimento nas \\ Organizações, Maringá, PR, Brasil. E-mail: arthur.urpia@unicesumar.edu.br; rejane.sartori@unicesumar.edu.br; \\ caiopisconti@gmail.com
}

How to cite: Urpia, A. G. B. C., Sartori, R., \& Machado, C. P. (2020). Practices of knowledge

management in organizational processes of town hall of the AMUSEP region: a research agenda.

Gestão \& Produção, 27(4), e4669. https://doi.org/10.1590/0104-530X4669-20

\begin{abstract}
This article aims to diagnose the implementation level and coverage regarding of the Knowledge Management practices related to the organizational processes in the municipalities associated to AMUSEP - Municipalities Association of the North of Paraná. Thus, our work is a quantitative and descriptive research based on multiple case studies. We collected data through a questionnaires in Google Forms. The outcomes point out that those municipalities have both low effective level of implementation and low coverage of Knowledge Management practices associated to the organizational processes. This result is critical given the importance of these practices for public organizations, since they act as facilitators of the processes of Knowledge Management.
\end{abstract}

Keywords: Knowledge management; Public sector; Organizational processes.

Resumo: O objetivo deste trabalho é diagnosticar o nível de implantação e o estágio de alcance das práticas de Gestão do Conhecimento relativas aos processos organizacionais nas prefeituras situadas na região da Associação dos Municípios do Setentrião Paranaense. A pesquisa, com abordagem quantitativa, configura-se como um estudo de casos múltiplos. Para a coleta de dados, utilizou-se um questionário elaborado na plataforma Google Forms e difundido para os participantes da pesquisa por meio de mensagem eletrônica. Os resultados evidenciam que as prefeituras analisadas possuem tanto um baixo nível efetivo de implantação quanto um baixo estágio de amplitude do alcance das práticas de Gestão do Conhecimento associadas aos processos organizacionais. Este resultado é crítico diante da importância dessas práticas para as organizações públicas, uma vez que atuam como facilitadores dos processos de Gestão do Conhecimento.

Palavras-chave: Gestão do conhecimento; Setor público; Processos organizacionais. 


\section{Introduction}

Knowledge has now become a fundamental and vital strategic resource for the good performance of organizations. As Mendoza et al. (2017) state, companies that know how to use their knowledge have a competitive advantage and because of their individuality, they have a differential advantage that is difficult for other companies to emulate. Thus, it is necessary to study effective mechanisms for the creation, exchange and dissemination of knowledge within organizations, as well as for knowledge transfer between them and the external environment. Therefore, it is up to Knowledge Management to design and manage strategies based on the creation and use of such knowledge (Ribeiro \& Izquierdo, 2017).

Knowledge Management represents a systematic and organized attempt to use knowledge within an organization in order to achieve better results (Edvinsson \& Malone, 1999). It resides in underlying structures used to collect, store and disseminate knowledge throughout the organization (Strakos et al., 2016). This is one of the main needs within any organization and is associated not only with Knowledge Management as a resource, but also with the processes that take place for such a resource to be used (García-Holgado \& García-Peñalvo, 2016). Therefore, Knowledge Management contributes to companies, through its organizational processes practices, to forming their strategies in such a way that they take advantage of business opportunities and better face the threats observed within the organizational environment (Batista, 2016).

Because it is a subject that seeks to respond to social and economic trends, and because of its importance and recognition by organizations nowadays, many national and international publications are found on Knowledge Management, thus revealing the interest in studying this theme (Balbino et al., 2016), with the majority focused on private organizations (Echternacht \& Quandt, 2017; Balbino et al., 2016). However, Knowledge Management can contribute to public sector organizations by increasing efficiency, innovating work processes and improving services to citizens in order to improve their quality of life and well-being (Echternacht \& Quandt, 2017; Batista, 2016).

A study by Massaro et al. (2015) reveals that Knowledge Management in the public sector as a research area has grown in importance in recent years, however, it highlights some problems, such as the existence of few authors specialized in the field; the level of collaboration between them and international comparisons is still low; and the leading journals dealing with the subject have published few works on Knowledge Management in Latin America in the last decade (Silva \& Miranda, 2018; Ribeiro \& Izquierdo, 2017; Batista, 2016). In addition, practices of sharing, transfer and knowledge management are little discussed and used by the Brazilian public sector and, consequently, there is a shortage of published studies (Silva \& Miranda, 2018; Ribeiro \& Izquierdo, 2017; Pacheco, 2015; Batista, 2012; Leocádio \& Santos, 2008), thus confirming a lack of research on Knowledge Management in the context of public sector organizations.

Public organizations can be defined as the activity that the state develops for the achievement of collective interests and, subjectively, as the set of organs and legal entities to which the law assigns the exercise of the state administrative function (Tavares, 1992). The role of the public administration is to act as a transmitting axis between the state and society, following principles of rationality and efficiency, contributing to the institutional strengthening and administrative modernization of these services, focused on responsibilities ranging from the formulation of public policies to its implantation, implementation and administrative execution (Salm \& Menegasso, 2009). Thus, as Echternacht \& Quandt (2017) state, public administration must be 
oriented towards the fulfilment of the welfare state, since this is the essential function of the state, which must carry it out directly, continuously and permanently.

Public administration is complex and very important in any society, mainly because it interferes in the social, economic, educational, health, cultural and quality aspects of life of a population (Pacheco, 2015; Wiig, 2000). For the most part, public agencies are characterized by extensive bureaucracies, following standardized norms and regulations, with vertical hierarchical structures, providing uniform services and having less incentive to innovation and teamwork than private initiative. Thus, there is now a constant demand from society for organizations from this sector, which do not operate with a common structure or have a standard organizational shape or size, to be transparent, effective and responsible for their activities (Sartori, 2011).

Management processes have a strong impact on the quality of services provided to society, which means that Knowledge Management, through its organizational processes practices, can contribute to improving the efficiency of the public service, since it helps such organizations face new challenges, implement innovative management practices, and improve the execution and quality of public processes, products and services for the benefit of the citizen-user and society in general (Batista, 2006, 2012).

As Wiig (2000) observes, Knowledge Management is fundamental for greater assertiveness in the decision-making actions performed within the public sector; helping the community participate effectively in the decision-making process; building competitive capacities in the development of the intellectual capital of society; and developing a Knowledge Management workforce in the public sector. Thus, Knowledge Management becomes a new responsibility to ensure the effectiveness of the public service in improving society which served by such administration (Almudallal et al., 2016).

Therefore, the purpose of this work is to diagnose the level of implementation and the stage of reach of the Knowledge Management practices concerning the organizational processes within the city halls located in the region of the Association of Municipalities of Setentrião Paranaense (AMUSEP). In this context, this research becomes relevant since it identifies the level of effectiveness of Knowledge Management within the city halls of such region, and this way, Knowledge Management practices can be suggested to help these organizations strengthen the effectiveness of the public service and add value to society as a whole.

This work is structured in five sections. In addition to this introduction, the second section discusses Knowledge Management within organizations, with emphasis on the public sector, and the third section presents the methodology used in this research. The fourth section is intended for research results and discussions. Finally, the fifth section presents the final considerations and recommendations for future investigations, followed by the bibliographic references used.

\section{Theoretical approach}

This section is about the conceptual bases inherent to the development of this research, which comprise Knowledge Management within organizations and the Public Administration. 


\subsection{Knowledge management within organizations}

Knowledge Management has attracted the attention of researchers and organizations for being an important business management tool that enables organizations to gain competitive advantage. For Moresi (2001), it is a set of activities whose purpose is to develop and control all types of knowledge existing within an organization, aiming to use it for the achievement of its goals.

There is a wide variety of Knowledge Management concepts. Dalkir (2011) found in his studies, more than one hundred definitions for the term and considers that a good definition for Knowledge Management is to incorporate capture and storage from the point of view of knowledge itself, together with the appreciation of intellectual assets. In this perspective, the author conceptualizes Knowledge Management as the deliberate and systematic coordination of people, technology and processes of an organization, and organizational structure, with the purpose of adding value through the reuse of knowledge and innovation, which is obtained by the promotion of creation, sharing and application of knowledge.

Fresneda et al. (2009) consider that Knowledge Management is a systematic, explicit and deliberate tool for the construction, renewal and application of knowledge, in order to maximize the effectiveness of the organization and the return of its knowledge assets. In a similar way, Maier (2007) considers Knowledge Management as the management function responsible for selecting, regulating, implementing and evaluating knowledge oriented towards strategic goals, which aim at the best way of manipulating internal and external knowledge to the organization with the purpose of improving organizational performance. According to the aforementioned author, the main goals of Knowledge Management are to reduce costs; improve productivity, increase the speed of innovation; develop new business; reduce risk, that is, improve responsiveness to market changes and loss of valuable knowledge for the organization; favor stakeholders' satisfaction; improve on the growth and development of the organization; and also improve service quality and response time.

In this way, Knowledge Management is seen as a process capable of managing, with excellence, the flow of knowledge that comprises different activities related to each other, in order to provide sustainable competitive advantages to organizations (Sousa, 2014).

To stay competitive in today's globalized scenario, impacted by technological advancement and ease of communication, organizations will either have to abandon old concepts and be ready for change, or they will become obsolete. In this sense, Knowledge Management practices allow to identify and use information and knowledge assets and improve the organization's capacity to mobilize knowledge in order to increase its performance. In particular, Knowledge Management practices concerning the organizational processes, which are addressed in the next section, help companies configure their strategies to better seize business opportunities and address the threats observed within the organizational environment.

\subsection{Organizational processes knowledge management practices}

When approaching on Knowledge Management practices, it is initially appropriate to examine the meaning of this expression so characteristic in this area. The term practice relates to the action performed by someone in a given circumstance. Thus, Knowledge Management practice refers to a human action that involves the 
management of intellectual capital in a specific situation (Cabral, 2017). For Batista (2006, p. 8), these are "[...] organizational management practices aimed at producing, retaining, disseminating, sharing and applying knowledge within organizations, as well as in their relation to the outside world". In this sense, Knowledge Management practice is characterized by such human action which takes place in a context that involves the management of intellectual capital, that is, knowledge that is in the possession of the people connected to the organization.

This expression should not be confused with the Knowledge Management tool. A Knowledge Management tool can be considered a means by which to achieve a result, or even a form of support for the execution of actions, practices and/or Knowledge Management processes (Cabral, 2017). Knowledge Management tools aim to support the achievement of Knowledge Management within the organization (Bento et al., 2016).

Thus, it is considered that the tools are used to support the implementation of Knowledge Management processes and are usually linked to the organization's technological and functional base (databases, software), to human networks or to different methodologies (Bento et al., 2016; Batista et al., 2005). Dalkir (2011) considers that the best Knowledge Management tools create knowledge and leverage it for several channels of access. Tools such as decision support systems, for instance, help knowledge workers better apply their knowledge of their activities.

In view of the purpose of this work, we chose to carry out a more extensive analysis of the Knowledge Management practices concerning organizational processes, such as: bench of individual competencies, benchmarking, intellectual capital management, knowledge mapping, best practices and organizational memory, competency management system and organizational intelligence system. Such practices are described below:

- Bench of individual competencies: refers to a repository of information that specifies in depth the human competencies (knowledge, skills and attitudes) in the organizational context, in addition to information about the scientific, artistic and cultural capacity of the collaborators (Machado et al., 2017; Bento et al., 2016; APQC, 2014; Batista, 2012, 2006; Carbone et al., 2009; Young, 2010; Purcidonio, 2008);

- Benchmarking: corresponds to a systematic search for the best references for comparison, for purposes of assimilation of processes, practices, products or services, in an effort to increase productivity, quality and organizational performance, allowing to identify organizational practices that provide superior performance, focusing efforts where it can create the best results for the company (Machado et al., 2017; APQC, 2014; Batista et al., 2014; Batista, 2006, 2012; Purcidonio, 2008; Massa \& Testa, 2004);

- Intellectual capital management: it is related to the management of human, structural and relationship assets, with a view to renewing, organizing, evaluating, protecting and increasing the availability of the assets that represent the knowledge present in the organizational scope (Bento et al., 2016; APQC, 2014; Freire \& Spanhol, 2014; Batista, 2006, 2012; Carbone et al., 2009; Young, 2010; Edvinsson \& Malone, 2003; Wiig, 2000; Davenport \& Prusak, 1998; Stewart, 1998);

- Knowledge mapping: it is related to the codification, through taxonomies or knowledge maps, allowing to identify the assets and the sources of tacit or explicit knowledge. It serves to locate, assess skills, opportunities, needs and constraints 
of knowledge (Bento et al., 2016; Lee \& Fink, 2013; Batista, 2006, 2012; Young, 2010; Driessen et al., 2007; Wiig, 2000; Davenport \& Prusak, 1998; Abecker et al., 1998);

- Best practices: refers to a methodology or approach for identifying, selecting and disseminating innovative practices, reliable know-how and processes that ensure better organizational performance (Machado et al., 2017; Bento et al., 2016; APQC, 2014; Batista et al., 2014; Batista, 2006, 2012; Perrin et al., 2010; Massa \& Testa, 2004);

- Organizational memory: it is related to the storage of explicit organizational knowledge in repositories about processes, products, services and relationships with stakeholders, involving content management resources and consultation and recovery mechanisms. It must happen in a collaborative way, by increasing and sharing knowledge, capturing, organizing, disseminating and reusing the knowledge created by the organization's employees. It offers the organization a greater competitive advantage by contributing to the improvement of organizational knowledge (Bento et al., 2016; APQC, 2014; Lee \& Fink, 2013; Batista, 2006, 2012; Young, 2010; Choo, 2002; Conklin, 2001; Wiig, 2000; Davenport \& Prusak, 1998; Abecker et al., 1998);

- Competency management system: a guidance for evaluating internal competencies, in order to determine which core competencies are necessary and define strategies to overcome competency deficiencies identified comparatively at the individual and organizational level (Machado et al., 2017; Bento et al., 2016; APQC, 2014; Araújo \& Martins, 2014; Batista et al., 2014; Batista, 2006, 2012; Young, 2010);

- Organizational intelligence system: establishes processes related to organizational learning through the transformation of data and information into intelligence. It includes the capture and conversion of information for knowledge extraction as a way to support managers in decision making. Knowledge obtained from internal or external, formal or informal sources, is formalized, documented and stored to facilitate access (Machado et al., 2017; Bento et al., 2016; Batista, 2006, 2012; Carbone et al., 2009; Choo, 2002; Davenport \& Prusak, 1998; Stewart, 1998).

\subsection{Knowlwdge management in the public administration}

Public Administration can be defined as "[...] the management of services and goods delivered to the community, in a qualitative way for the common good according to the orientation of law, laws, norms and others; and morality" (Braun \& Mueller, 2014, p. 986). In any society, it is considered important, although complex, because the viability and success of societies are largely explained by the way their public services are provided and how their resources can be leveraged, which includes the use of their natural resources, geographical location, personal capacities and intellectual capital (Wiig, 2000).

However, public bodies, mostly characterized by their extensive bureaucracies, following standardized norms and regulations, with vertical hierarchical structures, providing uniform services and having less incentive to innovation and teamwork than private initiative, need to be on a par with a rapidly changing knowledge and information based society. A simple observation in the way most of these organizations are conducted indicates that there is a lag concerning the agile and modern management 
techniques and organizational drawings related to the acquisition, generation and diffusion of knowledge in the day-to-day running of these organizations (Sousa, 2002; OCDE, 2003). Globally, governments understand they need to revitalize the public administration in order to favor service delivery by shifting its focus to the user with cost-effective and citizen-friendly alternatives, improving the quality of government functions (Mishra \& Mishra, 2012).

In a historical perspective, public administration evolved through three basic models: patrimonial, bureaucratic and managerial public administration. These three forms took place throughout time, without any of them being abandoned (Sartori, 2011). In the patrimonial view, a model that had been in force in Brazil since the arrival of the royal family in the early nineteenth century, the state was considered to be property of the government and its assets belonged to its rulers (Bresser-Pereira, 1996). In the bureaucratic view, a model used by several organizations since the 16th century, the focus was on building organizational structures that could achieve maximum organizational efficiency. This administration model was characterized by unity of command, hierarchical authority, and division of labor, with emphasis on technicality and the development of a career in the public administration (Denhardt \& Denhardt, 2003).

In the mid-1980s, driven by global economic crises and the crisis of the state itself, a management model called New Public Management (NPM) emerges. Such model is characterized by the application of the same premises which are applied within the public sector, within private companies in order to enable such companies to succeed in the market, focusing on issues such as as efficiency, accountability, agility and de-bureaucracy (Salm \& Menegasso, 2009). NPM's bases focus on citizens, results orientation, transparency and social control emphasis, management flexibility, and the valuation and development of people (Osborne \& Gaebler, 1995).

At that time, Brazil began to invest in the implementation of Information and Communication Technologies (ICTs) in the public sector, which resulted in great advances, generating a new culture, changing processes and mainly transforming the existing bureaucratic culture. These changes were accompanied by different ways of observing the structural field, changing norms, procedures and simplifying routines. It is at this point that Knowledge Management proves to be a valuable tool (Ribeiro et al., 2011).

In 2008, the United Nations (UN) conducted a study in the public sphere, which emphasizes that according to citizens, the advantages of Knowledge Management include better public services, more opportunities for choices, greater personalization in the service provided and greater control over how the treasury is spent (Pacheco et al., 2015). According to Arrau (2016), the public sector requires a different administration that recognizes the relevance of the tacit knowledge of its knowledge workers and manages it rationally in the pursuit of its goals. It is important to emphasize that the role of Knowledge Management in the Public Administration transcends the purpose of improving organizational performance and plays an important role in democratic society and also in inserting the country into the world economy (Batista et al., 2014), and this role must be in line with the strategic goals of this type of organization (Wiig, 2000).

In a broad analysis of the Brazilian organizational environment, Santos et al. (2001) state that, in the last three decades, managers of both private and public organizations, have become increasingly aware of the importance of reviewing their management models. In the case of private companies, motivation characterized their survival and 
competitiveness in the market; in the case of public companies, such motivation characterized their ability to accomplish their mission, that is, to provide quality services of interest to society. Thus, while the private sector implements Knowledge Management, focusing on profit and obtaining sustainable competitive advantages, Public Administration aims at quality, efficiency, social effectiveness and economic and social development (Braun \& Mueller, 2014; Batista, 2012; Brito et al., 2012).

In this perspective, Batista (2012) states that innovation, together with organizational learning, helps to increase the capacity of individual, team and organizational achievement and leads to an increase in social capacity. However, as Agune (2014) reports, little is known about the innovation process in non-market oriented sectors, thus so much work still needs to be done to study innovation and to develop a framework for collecting innovation data in the public sector.

In this way, it is perceived that a specific research agenda is required, since the public sector is organizationally peculiar because it has different concerns regarding effectiveness and critical situations, taking into account that real-time decisions can have consequences of high losses or social and collective gains (Massaro et al., 2015).

It is understood that the organizational structures, responsibilities, capacities, information, knowledge and intellectual capital of employees are factors that, in addition to affecting the performance of public organizations, can also be capacitors of organizational innovations that will bring new levels of performance to these organizations. Among these capacitors, intellectual capital assets are the main ones. They are the basic resources that govern the nature and directions of actions. This is said, because, without proper intellectual capital, even with the use of better sources of information, the actions of the servants will be based on ignorance, that is, on lack of understanding, being more arbitrary and ineffective than comprehensible and functional.

Quandt et al. (2006) point out that, in the specific context of Public Administration, the emergence of Knowledge Management initiatives is motivated by several factors, such as: i) the creation of pressure to increase efficiency and effectiveness of processes, budget constraints and administrative restructuring; ii) the need to register and adopt the best practices; iii) to avoid loss of knowledge with the departure of specialists responsible for the invention, capture and transfer of such knowledge; iv) the increasing diffusion of management models aimed at collaborative work, knowledge workers and the development and management of skills; and v) the increasing public demand for quick and appropriate solutions to their individual needs and specific problems, generating pressure for the acceleration of processes and responsiveness, requiring ways to overcome time and space barriers related to process execution and user service.

Furthermore, Massaro et al. (2015) argue that the public sector has different levels of representativeness, responsibility and responsiveness, which makes this field of research present specific challenges. One is the need for public sector professionals, particularly managers, to recognize that their organizations work in a single context in which their stakeholders and accountability differ significantly from those of the private sector. Therefore, blindly applying tools and models of knowledge management in the private sector can be counterproductive (Massaro et al., 2015).

Angelis (2011) considers that Public Administration should be involved with Knowledge Management due to the need for high adaptability and problem solving, in order to meet the needs of citizens, and the need for new models that seek to modernize management, in accordance with the requirements of society for quality 
services and transparency in the application of public resources. Thus, according to Wiig (2000), Knowledge Management plays an important role in making possible the introduction of new options, capacities and practices that can help Public Administration in achieving its goals.

According to Arrau (2016), Knowledge Management in the public sector obeys an urgent need to rationalize the use of information and organizational knowledge. In this context, Fresneda et al. (2009, p. 3) point out that

[...] thinking about knowledge management in Public Administration is to think first and foremost about the benefits it can bring to citizens, for increasing efficiency in the internal processes of public organizations, and for generating quality results for citizens.

Thus, managing knowledge becomes a new responsibility of the Public Administration to strengthen the effectiveness of the services provided and add value to society.

International experiences on Knowledge Management in the public sector are relevant to the understanding that this area has become relevant to Public Administration. Canada was one of the first to adopt a relevant constitutional structure for Knowledge Management in the public sector and has been prominent in the use of information and communication technologies in order for the State to interact with citizens in an agile way (Dalkir, 2016). In a traditional model of Public Administration, citizens request information and usually receive a paper copy. In the new model implemented in Canada, public agencies provide proactive disclosure to increase transparency and empowerment of citizens. This means that information is made available online and citizens can actively seek and retrieve the information they are interested in (Dalkir, 2016).

Based on the understanding that Knowledge Management is the basis for constant innovation in Public Administration, Heisig (2016) also presents a series of international experiences. For the author, the adoption of Knowledge Management practices in Austria, Germany, Switzerland and the United Kingdom provide evidence that the effective use of information and knowledge in the public sector is a relevant topic.

It's important to understand that the concept of Knowledge Management is still in constant evolution and therefore there are different conceptualizations and counterpoints present in the literature regarding knowledge and its management (Batista, 2006), and in the face of evidence that Knowledge Management has contributed for the improvement of the public sector in other countries, some researchers focused on specific aspects of Knowledge Management (Singh \& Gupta, 2014). Batista (2012) was one of them. In an initiative linked to the Institute of Applied Economic Research (IAER), such researcher developed a Knowledge Management model for the Brazilian public sector after concluding that Knowledge Management models built for the private sector are not suitable for the public sector, It is necessary to build a generic, holistic and specific model appropriate to the Brazilian Public Administration. In his work, the author analyzed the different definitions of Knowledge Management proposed for the Public Administration and adopted its own definition based on the approach of the Brazilian Public Administration, namely:

[...] an integrated method of creating, sharing and applying knowledge to increase efficiency; improve quality and social effectiveness; and contribute to legality, impersonality, morality and publicity in the Public Administration and for Brazilian development (Batista, 2012, p. 49). 
Knowledge Management practices help public organizations deal with the changes originated with the Information and Knowledge Age, especially those related to information and technology, contributing to identify, measure, disseminate and share the existing knowledge within the organization (Batista, 2012).

\section{Methodological procedures}

In order to reach the goal of this research, an investigation was initially made on the websites of the thirty city halls linked to AMUSEP, in order to detect the ones that contain, in their organizational structure, Secretariats for Administration. The choice for this type of department has occurred because, in the context of the municipal public sphere, these are the departments, according to Martins (2016), responsible for managing human resources, and oftentimes, procurement and bidding areas. Moreover, it is believed that, in general, the managers of these departments have knowledge related to the organizational management field, such as economics, administration, accounting, thus approaching this research's subject of study, that is, Knowledge Management.

The results of this investigation showed that fourteen city halls have Secretariats for Administration; four do not have Secretariats for Administration, but they have a Secretariat for Planning; six have neither a Secretariat for Administration nor a Secretariat for Planning; and six do not provide information from their Secretariats and/or their organizational structure on their websites. In view of these results and the purpose of this research, it was also decided to take into account the agencies of municipalities called Secretariats for Planning, since, according to Martins (2016), they are departments entrusted with a budget planning. In addition, it is assumed that their managers also have similar knowledge to the managers of the Secretaries for Administration. Thus, for the execution of this research the eighteen city halls that have Secretariats for Administration and/or Planning, we taken into account.

As regards technical procedures, this research is an exploratory survey, a type of survey designed to explore unknown phenomena and objects in research that uses primary data and adopts a quantitative approach (Paranhos et al., 2014). "In academic research, surveys are widely used to measure opinions, values, perceptions, and reports of individuals' experiences. They are the main quantitative approach focused on subjects" (CEBRAP, 2016, p. 16).

The research tool used to diagnose knowledge management practices in municipalities was a questionnaire developed by the Institute of Applied Economic Research (IAER), widely used and validated by several studies (Batista et al., 2007, 2014). Such questionnaire, which is specific to the diagnosis of the level of Knowledge Management in both public and private organizations, contains twenty-seven Knowledge Management practices and was elaborated "[...] from concrete examples observed in organizations of the world, encompassing practical applications, techniques, processes and tools" (Batista, 2006, p. 12). The questionnaire was adapted to broaden the understanding of the participants of the research, with a column containing the concepts of each practice and examples of its application in the context of the research.

The practices and actions present in the questionnaire, according to the classification used by Batista $(2006,2012)$, can be grouped into three categories: human resources, organizational processes and technological and functional basis. Practices and actions related mainly to aspects of human resource management 
facilitate the transfer, dissemination and sharing of information and knowledge. Practices and actions related to the structuring of the organizational processes act as facilitators of generation, retention, organization and dissemination of organizational knowledge. Finally, practices and actions whose central focus is the technological and functional base, support Organizational Knowledge Management, including the automation of information management, applications and information technology tools for capture, diffusion and collaboration.

For this research, whose purpose is to diagnose the level of implementation and the stage of reach the of Knowledge Management practices related to organizational processes, only the second category was analyzed.

The scale presented in Table 1 was used to present data on the implementation stage of the Knowledge Management practices surveyed. The scale presented in Table 2 was used to analyze the stage of reach of the Knowledge Management practices surveyed.

Table 1. Scale for the analysis of the results concerning the implementation stage of Knowledge Management practices.

\begin{tabular}{cl}
\hline Level & \multicolumn{1}{c}{ Description } \\
\hline$[0]$ & There are no plans for the implementation of the practice \\
\hline$[1]$ & There are actions planned for the implementation of the practice in the future \\
\hline$[2]$ & The practice is under implementation \\
\hline$[3]$ & The practice has already been implemented \\
\hline$[4]$ & $\begin{array}{l}\text { The practice has already been implemented and presents important and relevant } \\
\text { result for the organization }\end{array}$ \\
\hline
\end{tabular}

Source: Created by the authors.

Table 2. Scale for the analysis of the results concerning the stage of reach of Knowledge Management practices.

\begin{tabular}{cl}
\hline Level & \multicolumn{1}{c}{ Description } \\
\hline$[1]$ & Isolated initiatives within the organization \\
\hline$[2]$ & Some departments use such practice \\
\hline$[3]$ & Many departments use such practice \\
\hline$[4]$ & Widely disseminated within the organization \\
\hline
\end{tabular}

Source: Created by the authors.

As regards the analysis of the results concerning the level of effectiveness in the implementation of the selected practices, only the responses related to levels 3 (the practice has already been implemented) and 4 (the practice has already been implemented and presents important and relevant results for the organization) of the scale were analyzed, considering that only at these two levels practices are already effectively implemented within the institutions analyzed.

Regarding the analysis of the result concerning the level of breadth of reach of the selected practices, only the responses related to levels 3 (several departments use such practice) and 4 (widely disseminated in the organization) of the scale were analyzed, this is due to the fact that only the responses of these two levels indicate that the analyzed practices have a wide reach. 
Table 3 presents the scale for the analysis of the results regarding the level of effectiveness in the implementation and level of breadth of reach of the Knowledge Management practices related to the organizational processes. It is important to highlight that the parameters were created in an arbitrary way, however, they were found to be convenient in the structure of the Secretariats analyzed.

Table 3. Scale for the analysis of the results concerning the level of effectiveness in the implementation and stage of breadth of reach of Knowledge Management practices.

\begin{tabular}{cc}
\hline $\begin{array}{c}\text { Level of effectiveness in the } \\
\text { implementation and reach }\end{array}$ & Stages $\mathbf{3 + 4}$ \\
\hline Low level & Between 0 to $39 \%$ \\
\hline Average level & Between $40 \%$ to $60 \%$ \\
\hline High Level & Above $60 \%$ \\
\hline
\end{tabular}

Source: Created by the authors.

The questionnaire was created on the Google Forms platform, one of the main "[...] platforms that offer services for building online questionnaires and conducting web surveys" (CEBRAP, 2016, p. 57), and disseminated to managers of the eighteen city halls by means of an electronic message. In this way, the survey covered the entire universe of the selected city halls and the data collected reflect the managers' perception of these city halls, which, like these departments, were not identified for the purpose of keeping the information confidential.

It should be emphasized that before sending the questionnaire the researchers contacted the managers by telephone to inform them about the research and request participation. Data collection occurred between January and March 2017.

For the analysis of the results collected through the questionnaire, a quantitative approach was taken. The results were obtained by using descriptive statistics techniques, such as absolute and relative frequency distribution analysis of the data. The organization of the data and the calculation of the statistics were done by using Microsoft Excel version 2010.

In this way, the methodological procedure used in this research followed the steps that constitute the planning of a survey, which are: identification of the research question; use of a validated research tool; definition of the sample; sending of the research tool through the Google Forms platform; collection, tabulation and analysis of data.

\section{Results and discussion}

Management processes have a strong impact on the quality of services provided by public organizations, which means that Knowledge Management, through its organizational processes practices, contributes to improving the efficiency of the public service, since such practices help in the execution of procedures and application of organizations' norms and rules (Batista, 2006).

Despite the importance of these practices for public organizations, the results obtained from the diagnosis made with the municipalities of the AMUSEP region show that all Knowledge Management practices associated with organizational processes, i.e., competency bank, internal and external benchmarking, intellectual capital management, knowledge mapping or audit, best practices, organizational memory, 
competency management system, and organizational intelligence systems, have both an effective implementation level and a low level of breadth of reach, as shown in Figure 1.

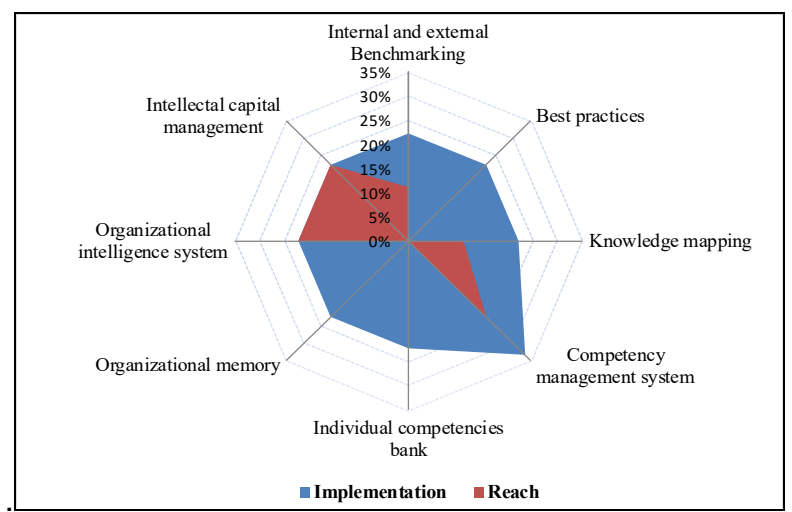

Figure 1. Integrated result for the level of effectiveness in the implementation and stage of breadth of reach of the organization process Knowledge Management practices. Source: Created by the authors using the research data.

Internal and external benchmarking, which "[...] allows to identify organizational practices that provide superior performance, focusing efforts on where it will create the best results for the company" (Purcidonio, 2008, p. 60), is effectively deployed to only $22.2 \%$ of the managers, since none of the managers indicated stage 3 (the practice has already been implemented) and $22.2 \%$ indicated stage 4 (the practice is already implemented and presents important and relevant results for the organization). In addition, $55.6 \%$ of the managers reported that there were no plans to implement this practice.

Regarding the level of breadth of reach of such practice, it was also observed that it is also low, since none of the managers pointed to the practice as being widely disseminated within their organization (stage 3 ) and only $11 \%$ indicated that many departments use this practice (stage 4). Meanwhile, $55.6 \%$ of managers responded that there are isolated initiatives within their organizations and $33.3 \%$ said that only a few departments use the practice. These results, which are present in Table 4 (implementation stage) and Table 5 (reach stage), are worrisome, as they demonstrate that city halls are not seeking better references to support the formulation of their processes and services. The implementation of internal and external benchmarking could make city hall employees and managers aware of the possibility of increasing the quality of the services provided, in addition to creating a more entrepreneurial behavior.

Table 4. Implementation stage of Knowledge Management practices concerning the organizational process.

\begin{tabular}{llcccc}
\hline \multirow{2}{*}{\multicolumn{1}{c}{ Action or Practice }} & \multicolumn{5}{c}{ Stage of Implementation } \\
\cline { 2 - 6 } & $\mathbf{0}$ & $\mathbf{1}$ & $\mathbf{2}$ & $\mathbf{3}$ & $\mathbf{4}$ \\
\hline Internal and external Benchmarking & $55.6 \%$ & $11.1 \%$ & $11.1 \%$ & $0.0 \%$ & $22.2 \%$ \\
\hline Best practices & $66.7 \%$ & $0.0 \%$ & $11.1 \%$ & $11.1 \%$ & $11.1 \%$ \\
\hline Knowledge mapping & $66.7 \%$ & $0.0 \%$ & $11.1 \%$ & $22.2 \%$ & $0.0 \%$ \\
\hline Competency management system & $55.6 \%$ & $0.0 \%$ & $11.1 \%$ & $22.2 \%$ & $11.1 \%$ \\
\hline Indivudual competencies bank & $77.8 \%$ & $0.0 \%$ & $0.0 \%$ & $11.1 \%$ & $11.1 \%$ \\
\hline Organizacional memory & $66.7 \%$ & $0.0 \%$ & $11.1 \%$ & $11.1 \%$ & $11.1 \%$ \\
\hline
\end{tabular}




\begin{tabular}{lllllc}
\hline \multirow{2}{*}{\multicolumn{1}{c}{ Action or Practice }} & \multicolumn{5}{c}{ Stage of Implementation } \\
\cline { 2 - 6 } & $\mathbf{0}$ & $\mathbf{1}$ & $\mathbf{2}$ & $\mathbf{3}$ & $\mathbf{4}$ \\
\hline Organizacional intelligence system & $55.6 \%$ & $11.1 \%$ & $11.1 \%$ & $22.2 \%$ & $0.0 \%$ \\
\hline Intellectual capital management & $55.6 \%$ & $11.1 \%$ & $11.1 \%$ & $0.0 \%$ & $22.2 \%$ \\
\hline
\end{tabular}

Grade: (0) There are no plans for the implementation of the practice; (1) planned for the future; (2) under implementation; (3) already been implemented; (4) implemented and presenting relevant results. Source: Created by the authors by using the research data.

Table 5. Stage of reach of Knowledge Management practices concerning organizational process.

\begin{tabular}{lrrrc}
\hline \multirow{2}{*}{\multicolumn{1}{c}{ Action or Practice }} & \multicolumn{4}{c}{ Reach } \\
\cline { 2 - 5 } & $\mathbf{1}$ & $\mathbf{2}$ & $\mathbf{3}$ & $\mathbf{4}$ \\
\hline Internal and external Benchmarking & $55.6 \%$ & $33.3 \%$ & $0.0 \%$ & $11.1 \%$ \\
\hline Best practices & $66.7 \%$ & $33.3 \%$ & $0.0 \%$ & $0.0 \%$ \\
\hline Knowledge mapping & $66.7 \%$ & $22.2 \%$ & $0.0 \%$ & $11.1 \%$ \\
\hline Competency managemente system & $77.8 \%$ & $0.0 \%$ & $11.1 \%$ & $11.1 \%$ \\
\hline Indivudual competencies bank & $88.9 \%$ & $11.1 \%$ & $0.0 \%$ & $0.0 \%$ \\
\hline Organizacional memory & $88.9 \%$ & $11.1 \%$ & $0.0 \%$ & $0.0 \%$ \\
\hline Organizacional intelligence system & $66.7 \%$ & $11.1 \%$ & $22.2 \%$ & $0.0 \%$ \\
\hline Intellectual capital management & $66.7 \%$ & $11.1 \%$ & $0.0 \%$ & $22.2 \%$ \\
\hline
\end{tabular}

Grade: (1) few isolated initiatives; (2) restricted to some departments; (3) several departments adopt such practice; (4) widely disseminated within the organization. Source: Created by the authors.

Best practices, knowledge mapping or auditing and organizational memory are practices that have been identified as having a low level of effectiveness in their implementation in city halls (Figure 1). It is important to note that $66.7 \%$ of the managers reported that there are no plans for implementing these three practices in city halls and $11.1 \%$ reported that these practices are in the process of being implemented, as shown in Table 4. The level of breadth of reach of these practices is also low. For best practices, $66.7 \%$ of the managers reported that there are few isolated initiatives and for $33.3 \%$ the practice is restricted to some departments. Likewise, for the practice of mapping or auditing knowledge, $66.7 \%$ of managers answered that there are few isolated initiatives in their organizations, while $22.2 \%$ of them understand that the practice is restricted to some departments, and also to $11,1 \%$ of managers practice is widely disseminated in their organizations. Regarding the practical organizational memory, $88.9 \%$ of the managers indicated that there are few isolated initiatives in their organizations and $11.1 \%$ of them pointed out the practice as limited to a few departments.

Such results are critical in view of the role and importance of each of these practices: best practices contribute to identifying, capturing and sharing best practices in various organizational activities (Bento et al., 2016); knowledge mapping or auditing is a process by which organizations can identify and categorize knowledge assets (Young, 2010); organizational memory increases and shares knowledge, which captures, organizes, disseminates and reuses the knowledge created by the organization's employees (Conklin, 2001). Abecker et al. (1998) argue that organizational memory, in addition to explicit knowledge, provides the organization with a greater competitive advantage by contributing to the improvement of organizational knowledge. 
Thus, it is observed that practices that directly manage knowledge, such as knowledge mapping and organizational memory, and that contribute to the improvement of city halls services, such as best practices, are not being used according to their potential because of the low level of effectiveness in their implementation and the equally low breadth of reach. With this, it is observed that city halls still need to evolve in order to recognize the relevance of their workers' tacit knowledge, in addition to managing it in a way to increase the quality of the services provided.

An even more disturbing result obtained with the diagnosis concerns the use of the individual skills bench practice. This practice, which consists of a repository of information about the technical, scientific, artistic and cultural capacity of people (Batista et al., 2014), was pointed out by $22.2 \%$ of the managers as effectively implemented, and the other managers, $77.8 \%$ reported no plans for their implementation in city halls, as shown in Table 4 . Regarding their stage of reach (Table 5), $88.9 \%$ of the managers reported that there are few isolated initiatives in their organizations and $11.1 \%$ understand that the practice is restricted to some departments. Given this result, it is observed that city halls must face difficulties in allocating employees who have real expertise in a subject or problem to be solved, which affects the quality of the public service, given the absence of an information repository on the technical, scientific, artistic and cultural capacity of its collaborators.

The result obtained with the practice related to the management system by competency, serves in a way, to justify the result found through the individual competencies bank practice, since the latter, which aims at defining the knowledge and skills necessary to overcome the existing deficiencies in concerning the level desired for the organization (Batista, 2006), showed a low level of effectiveness in the implementation $(33.3 \%)$ and a low level of breadth of reach $(22.2 \%)$, as shown in Figure 1. That is, the results of the individual competency bank and competency management system practices are consistent and demonstrate a certain inability of city halls to define the knowledge and skills needed to overcome the existing deficiencies, which also impairs the allocation of employees who have knowledge and experience on issues or problems that must be resolved by the city halls.

On the other hand, the practices related to the organizational intelligence and intellectual capital management systems presented similar results, since only $22.2 \%$ of the managers reported that these practices were effectively implemented, while $55.6 \%$ of the managers pointed out that there are no plans for the implementation of these practices in the city halls. As regards the stage of reach of these practices, $66.7 \%$ of the managers indicated that there are few isolated initiatives in their organizations and $11.1 \%$ answered that the practices are restricted to some departments.

Organizational intelligence systems, according to Batista (2006, p. 22), are "[...] aimed at transforming data into intelligence, in order to support decision-making. Knowledge gained from internal or external, formal or informal sources, is formalized, documented and stored to facilitate access". In this way, it is verified that this practice contributes to promote organizational learning and thus facilitates decision-making, which is crucial to improve services provided by city halls. Such systems tend to contribute to the formation of another practice related to organizational processes, the management of intellectual capital, defined as the merge of intangible assets (talents, ideas and insights presented by all those involved in the organizational context), as well as quality and harmony between companies, suppliers and customers (Bento et al., 2016). In view of the importance of such practices to improve the quality 
of services provided by city halls, it is necessary to create effective measures to increase the implementation and reach of these practices in the city halls analyzed.

\section{Final considerations}

This study presents the results of the diagnosis performed in the city halls linked to AMUSEP in order to diagnose the level of implementation and the stage of reach of Knowledge Management practices related to organizational processes.

The results obtained by the research demonstrate that such practices, in general, have both a low level of effectiveness in their implementation and an equally low stage of breadth of reach, in the city halls analyzed. It is important to highlight that practically more than $50 \%$ of the managers participating in the research have the perception that there are no plans to implement the Knowledge Management practices related to organizational processes in their city halls. Such result is critical in view of the importance of these practices for public organizations, since they act as facilitators of Knowledge Management processes, that is, regarding the identification, creation, storage, dissemination and application of organizational knowledge. This result is equally worrying given the general characteristics of public bodies in Brazil, which are mostly recognized for their extensive bureaucracies, following standardized norms and regulations, with vertical hierarchical structures, providing uniform services and having less incentives for innovation and teamwork than private initiative.

However, given the results obtained by the performed diagnosis, there is a window of opportunities for the implementation of these Knowledge Management practices in the city halls analyzed, thus helping them increase the efficiency of the public service and thus, increase the level of well-being of the population. In this sense, it is important to point out that authors have been working to create scripts and theoretical models that contribute to the implementation of Knowledge Management practices in public bodies, such as Machado (2017). This author suggests the creation of a conceptual model of implementation of Knowledge Management practices related to organizational processes for Brazilian public schools. This model is formulated from three basic concepts: i) a strategic conception of information and knowledge; (ii) the introduction of such a strategy at the tactical and operational levels through various managerial approaches and tools geared to information and knowledge issues; and iii) the creation of an enabling environment, which is about favorable conditions that must be provided by public bodies so that the latter can always use the best information and the best knowledge available (Machado, 2017). The application of models, such as that suggested by Machado, can contribute to the city halls analyzed consolidate Knowledge Management processes and thus, provide more efficient and higher quality public services.

In this sense, new perspectives have been created for future works, such as the possibility to diagnose the level of Knowledge Management in other Secretariats of the same city halls and to carry out comparative studies with similar works in other locations. In addition, it is necessary to identify strategies and mechanisms for the consolidation of Knowledge Management in the city halls analyzed. Another possibility consists of the execution of the research in other companies of the public sector. 


\section{References}

Abecker, A., Bernardi, A., Hinkelmann, K., Kuhn, O., \& Sintek, M. (1998). Toward a technology for organizational memories. IEEE Intelligent Systems \& their Applications, 13(3), 40-48. http://dx.doi.org/10.1109/5254.683209.

Agune, R. (2014). O governo no século XXI. In R. Agune, A. Gregorio, A. Neves, I. M. Dias, J. A. Carlos \& S. Bolliger (Eds.), Dá pra fazer: gestão do conhecimento e inovação em governo. São Paulo: Secretaria de Planejamento e Desenvolvimento Regional.

Almudallal, A. W., Bakri, N., Mujtar, S. N., \& El-Farra, M. M. (2016). Implementing knowledge management in the palestinian public sector institutions: empirical study on the Presidency of the Palestinian Government. International Review of Management and Marketing, 6(4), 101-107.

American Productivity and Quality Centre - APQC. (2014). Knowledge management glossary. Houston: APQC.

Angelis, C. T. (2011). Gestão do Conhecimento no setor público: um estudo de caso por meio do método OKA. Revista do Serviço Público, 62(2), 137-166. http://dx.doi.org/10.21874/rsp.v62i2.66.

Araújo, J. A., Jr., \& Martins, I. (2014). Gestão por competências na administração pública: uma análise bibliométrica a partir do decreto Lei 5.707/2006. Revista Eletrônica de Gestão Organizacional, 12(2), 153-162. Retrieved in 2017, December 5, from http://www.spell.org.br/documentos/ver/39905/gestao-por-competencias-na-administracaopublica--uma-analise-bibliometrica-a-partir-do-decreto-lei-5-707-2006

Arrau, G. P. (2016). Gestión del conocimiento en el sector público chileno. In F. F. Batista (Ed.), Experiências internacionais de implementação da gestão do conhecimento no setor público. Rio de Janeiro: IPEA.

Balbino, J. N., Silva, H. F. N., \& Queiroz, F. C. B. P. (2016). O estágio de desenvolvimento da gestão do conhecimento nos Institutos Federais de Educação, Ciência e Tecnologia. Perspectivas em Gestão \& Conhecimento, 6(2), 80-98.

Batista, F. F. (2006). O desafio da gestão do conhecimento nas áreas de administração e planejamento das Instituições Federais de Ensino Superior (IFES) (Texto para Discussão, No. 1181). Brasília: Ipea.

Batista, F. F. (2012). Modelo de gestão do conhecimento para a administração pública brasileira: como implementar a gestão do conhecimento para produzir resultados em benefício do cidadão. Brasília: Ipea.

Batista, F. F. (Ed.) (2016). Experiências internacionais de implementação da gestão do conhecimento no setor público. Rio de Janeiro: Ipea.

Batista, F. F., Quandt, C. O., Pacheco, F. F., \& Terra, J. C. C. (2005). Gestão do conhecimento na administração pública (Texto para Discussão, No. 1095). Brasília: Ipea.

Batista, F. F., Rech, A. R., Gomes, C. A., Santos, D. L. N., Andrade, E. C. S., Mallmann, M. L., Ferreira, R. M. P. M., \& Costa, V. da S. (2014). Casos reais de implantação do modelo de gestão do conhecimento para a administração pública brasileira (Texto para Discussão, No. 1941). Brasília: Ipea.

Batista, F. F., Xavier, A. C. R., Mendes, L. C., \& Rosenberg, G. (2007). Gestão do conhecimento em organizações públicas de saúde (Texto para Discussão, No. 1316). Brasília: Ipea.

Bento, J. C., Massuda, E. M., Urpia, A. G. B. da C., \& Bortolozzi, F. (2016). Práticas da gestão do conhecimento em recursos humanos em instituição de ensino superior à distância. Espacios, 37(29), 21-30.

Braun, C. C., \& Mueller, R. R. (2014). A gestão do conhecimento na administração pública municipal em Curitiba com a aplicação do método OKA - Organizational Knowledge 
Assessment. Revista de Administração Pública, 48(4), 983-1006. http://dx.doi.org/10.1590/0034-76121620.

Bresser-Pereira, L. C. (1996). Da administração pública burocrática à gerencial. Revista do Serviço Público, 47(1), 7-40.

Brito, L. M. P., Oliveira, P. W. S., \& Castro, A. B. C. (2012). Gestão do conhecimento numa instituição pública de assistência técnica e extensão rural do Nordeste do Brasil. Revista de Administração Pública, 46(5), 1342-1366.

Cabral, M. P. Gestão do conhecimento no ensino público: um estudo de caso em escolas públicas participantes do PEEB. 2017. Dissertação de Mestrado. Centro Universitário Cesumar, Maringá.

Carbone, P. P., Brandão, H. P., Leite, J. B. D., \& Vilhena, R. M. de P. (2009). Gestão por competências: gestão do Conhecimento. Rio de Janeiro: Editora FGV.

Centro Brasileiro de Análise e Planejamento - CEBRAP (2016). Métodos de pesquisa em Ciências Sociais: bloco quantitativo. São Paulo: Sesc São Paulo/CEBRAP.

Choo, C. W. (2002). Information management for the intelligent organization: the art of scanning the environment. (3rd ed.). Medford: Information Today.

Conklin, J. (2001). Designing organizational memory: preserving intellectual assets in a knowledge economy. Retrieved in 2017, August 1, from http://cognexus.org/dom.pdf

Dalkir, K. (2011). Knowledge management in theory and practice. Cambridge: The MIT Press.

Dalkir, K. (2016). Knowledge management in the public sector: some canadian success factors. In F. F. Batista (Ed.), Experiências Internacionais de implementação da gestão do conhecimento no setor público. Rio de Janeiro: IPEA.

Davenport, T. H., \& Prusak, L. (1998). Conhecimento empresarial: como as organizações gerenciam o seu capital intelectual. Rio de Janeiro: Campus.

Denhardt, J. V., \& Denhardt, R. B. (2003). The new public service: serving not steering. Armonk: M. E. Sharpe.

Driessen, S., Huijsen, W., \& Grootveld, M. (2007). A framework for evaluating knowledgemapping tools. Journal of Knowledge Management, 11(2), 109-117. http://dx.doi.org/10.1108/13673270710738960.

Echternacht, T. H. S., \& Quandt, C. O. (2017). A gestão do conhecimento como suporte ao processo estratégico na administração pública municipal: um estudo comparativo de casos no Brasil e em Portugal. Perspectivas em Gestão \& Conhecimento, 7(1), 35-49.

Edvinsson, L., \& Malone, M. S. (1999). El capital Intelectual: cómo identificar y calcular el valor de los recursos intangibles de su empresa. Barcelona: Gestión.

Edvinsson, L., \& Malone, M. S. (2003). El capital intelectual: cómo identificar y calcular el valor inexplorado de los recursos intangibles de su empresa. Barcelona: Gestión.

Freire, P. S., \& Spanhol, F. J. (2014). Conhecimento organizacional: produto ou processo? Perspectivas em Gestão \& Conhecimento, 4(1), 3-21.

Fresneda, P. S. V., Gonçalves, S. M. G., Papa, M., \& Fonseca, A. F. (2009). Diagnóstico da gestão do conhecimento nas organizações públicas utilizando o método Organizational Knowledge Assesment (OKA). In Anais do I/ Congresso Consad de Gestão Pública (pp. 1-23). Brasília: Consad. Retrieved in 2018, February, from http://consad.org.br/wpcontent/uploads/2013/02/DIAGN\%C3\%93STICO-DA-GEST\%C3\%83O-DO-CONHECIMENTONAS-ORGANIZA \%C3\%87\%C3\%95ES-P\%C3\%9ABLICAS-UTILIZANDO-OM\%C3\%89TODO-ORGANIZATIONAL-KNOWLEDGE-ASSESSMENT-OKA2.pdf

García-Holgado, A., \& García-Peñalvo, F. (2016). Architectural pattern to improve the definition and implementation of eLearning ecosystems. Science of Computer Programming, 129, 20-34. http://dx.doi.org/10.1016/j.scico.2016.03.010. 
Heisig, P. (2016). Knowledge management in public administration in four european countries: examples from austria, germany, switzerland and the united kingdom. In F. F. Batista (Ed.), Experiências Internacionais de implementação da gestão do conhecimento no setor público. Rio de Janeiro: IPEA.

Lee, J., \& Fink, D. (2013). Knowledge mapping: encouragements and impediments to adoption. Journal of Knowledge Management, 17(1), 16-28. http://dx.doi.org/10.1108/13673271311300714.

Leocádio, L., \& Santos, J. L. (2008). Gestão do Conhecimento em Organizações Públicas: transferência de conhecimento suportada por tecnologias da informação e comunicação. São Paulo: KM BRASIL.

Machado, C. P. (2017). Práticas de gestão do conhecimento de processos organizacionais no contexto escolar: proposta de um modelo teórico-conceitual (Dissertação de mestrado). Centro Universitário de Maringá, Maringá.

Machado, C. P., Urpia, A. G. B. da C., \& Forno, L. F. D. (2017). Gestão do conhecimento no ensino público: uma agenda de pesquisa. Revista Cesumar, 22(1), 145-165. http://dx.doi.org/10.17765/1516-2664.2017v22n1p145-165.

Maier, R. (2007). Knowledge management systems: information and communication technologies for knowledge management. Berlin: Springer Science \& Business Media.

Martins, M. H. (2016). Gestão Pública: como funciona a Prefeitura? Organização da administração pública municipal. Retrieved in 2018, June, from http://gestaopublica.net/blog/como-funciona-a-prefeitura-organizacao-da-administracaopublica-municipal/

Massa, S., \& Testa, S. (2004). Innovation or imitation? Benchmarking: a knowledgemanagement process to innovate services. Benchmarking, 11(6), 610-620. http://dx.doi.org/10.1108/14635770410566519.

Massaro, M., Dumay, J., \& Garlatti, A. (2015). Public sector knowledge management: a structured literature review. Journal of Knowledge Management, 19(3), 530-558. http://dx.doi.org/10.1108/JKM-11-2014-0466.

Mendoza, C., Bischoff, J., \& Willy, C. (2017). Measuring the value of knowledge management practices at government research and development centers. Knowledge and Process Management, 24(1), 14-22. http://dx.doi.org/10.1002/kpm.1526.

Mishra, A., \& Mishra, D. (2012). E-government: exploring the different dimensions of challenges, implementation, and success factors. ACM SIGMIS Database, 42(4), 23-37. http://dx.doi.org/10.1145/2096140.2096143.

Moresi, E. A. D. (2001). Gestão da informação e do conhecimento. In K. Parapanoff (Ed.), Inteligência organizacional e competitiva. Brasília: Universidade de Brasília.

Organização para a Cooperação e Desenvolvimento Econômico - OCDE. (2003). Conclusões dos resultados da pesquisa das práticas de gestão do conhecimento nos ministério/departamentos/agências do governo central nos países membros da OCDE. Paris: OCDE.

Osborne, D., \& Gaebler, T. (1995). Reinventando o governo: como o espírito empreendedor está transformando o setor público (7. ed.). Brasília: MH Comunicação.

Pacheco, D. C. (2015). Maturidade em gestão do conhecimento da Prefeitura Municipal de Criciúma: o caso dos setores de convênios (Dissertação de mestrado). Programa de Pósgraduação, Universidade Federal de Santa Catarina, Florianópolis.

Pacheco, R. M., Rochinski, A., Peñaloza, A. L. L., \& Pinto, C. R. S. C. (2015). Gestão do conhecimento na administração pública brasileira: seu papel na promoção da sustentabilidade. In Anais do $11^{\circ}$ Congresso Nacional de Excelência em Gestão. Rio de Janeiro: CNEG. 
Paranhos, R., Figuereido, D. B., Fo., Rocha, E. C., \& Silva, J. A., Jr. (2014). Corra que o survey vem aí.: noções básicas para cientistas sociais. Revista Latinoamericana de Metodología de la Investigación Social, 6, 7-24.

Perrin, A., Rolland, N., \& Stanley, T. (2010). Achieving best practices transfer perspective on teacher professional development. Computers in Human Behavior, 26(1), 168-175.

Purcidonio, P. M. (2008). Práticas de gestão do conhecimento em arranjo produtivo local: o setor moveleiro de Arapongas - PR (Dissertação de mestrado). Universidade Tecnológica Federal do Paraná, Ponta Grossa.

Quandt, C. O., Terra, J. C. C., \& Batista, F. F. (2006). Gestão do conhecimento na administração pública: estágio de implantação, nível de formalização e resultados das iniciativas do governo federal brasileiro. In Anais do $30^{\circ}$ Encontro da Associação Nacional de Pós-graduação e Pesquisa em Administração. Maringá: Anpad.

Ribeiro, C. P. P., Pereira, A. D. S., Silva, E. A., \& Faroni, W. (2011). Dissemination of information within the public sector. Transinformação, 23(2), 159-171. http://dx.doi.org/10.1590/S0103-37862011000200006.

Ribeiro, E. M., \& Izquierdo, O. C. (2017). Gestão do conhecimento e governança no setor público (1. ed.). Salvador: UFBA.

Salm, J. F., \& Menegasso, M. E. (2009). Os modelos de administração pública como estratégias complementares para a coprodução do bem público. Revista de Ciências da Administração, 11(25), 97-120.

Santos, A. R., Pacheco, F. F., Pereira, H. J., \& Bastos, P. A., Jr. (2001). Gestão do conhecimento como modelo empresarial. In A. R. Santos, F. F. Pacheco, H. J. Pereira \& P. A. Bastos Jr. (Eds.), Gestão do conhecimento: uma experiência para o sucesso empresarial (pp.11-48). Curitiba: Universitária.

Sartori, R. (2011). Governança em agentes de fomento dos sistemas regionais de CT\&I (Tese de doutorado). Programa de Pós-graduação em Engenharia e Gestão do Conhecimento, Universidade Federal de Santa Catarina, Florianópolis.

Silva, A. P. N., \& Miranda, A. C. D. (2018). Gestão do conhecimento no setor público: um estudo sobre os artigos publicados em periódicos nacionais no período 2005-2015. Encontros Bibli: Revista Eletrônica de Biblioteconomia e Ciência da Informação, 23(52), 73-83. http://dx.doi.org/10.5007/1518-2924.2017v23n52p73.

Singh, R. M., \& Gupta, M. (2014). Knowledge management in teams: empirical integration and development of a scale. Journal of Knowledge Management, 18(4), 777-794. http://dx.doi.org/10.1108/JKM-11-2013-0450.

Sousa, A. D. D. (2002). As práticas de gestão de conhecimento nas organizações públicas: 0 ministério da justiça (Dissertação de mestrado). Escola Brasileira de Administração Pública, Fundação Getúlio Vargas, Rio de Janeiro.

Sousa, M. A. B. (2014). Gestão do Conhecimento: uma contribuição ao seu entendimento. Revista de Administração e Negócios da Amazônia, 6(3), 1-10. $\mathrm{http}: / / \mathrm{dx}$.doi.org/10.18361/2176-8366/rara.v6n3p38-47.

Stewart, T. A. (1998). Capital intelectual: a nova vantagem competitiva das empresas (2. ed.). Rio de Janeiro: Campus.

Strakos, J. K., Quintanilla, J. A., \& Huscroft, J. R. (2016). Department of Defense energy policy and research: a framework to support strategy. Energy Policy, 92, 83-91. http://dx.doi.org/10.1016/j.enpol.2016.01.036.

Tavares, J. (1992). Administração pública e direito administrativo. Coimbra: Almedina.

Wiig, K. M. (2000). Knowledge management in public administration. Journal of Knowledge Management, 6(3), 224-239. http://dx.doi.org/10.1108/13673270210434331.

Young, R. (2010). Knowledge management: tools and techniques manual. Tokio: Asian Productivity Organization. 